\title{
Respon Viabilitas Dan Vigor Benih Kakao (Theobroma cacao L.)" Pada Perbedaan Letak Biji Dalam Buah Dan Lama Pengeringan Benih
}

\author{
Response Of Viability And Vigor Of Cocoa Seeds \\ (Theobroma cacao, L.) On The Difference In Location Of Seeds \\ On Fruit And Old Drying Seeds
}

Muhammad Rafli

\begin{abstract}
This study aims to determine the effect of differences location and the decreasing of moisture content of cocoa seeds to influence the viability and vigor of cocoa seeds. This study used a completely randomized design factorial with three replications. There are 2 factors: cocoa seeds location $(L)$ consisting of 3 levels: cocoa seeds in the first part of fruit $\left(L_{1}\right)$, cocoa seeds in the middle of fruit $\left(L_{2}\right)$, cocoa seeds at the end of fruit $\left(L_{3}\right)$ and drying of cocoa seeds $(D)$ consists of 3 levels: without drying $\left(D_{0}\right), 1$ day of drying $\left(D_{1}\right), 2$ day of drying $\left(D_{2}\right)$. The results revealed that the treatment of location of cocoa seeds had a significant effect of the viability and seed vigor, except for seed growth potential and dry weight of cocoa seeds sprout. The best treatment was found of 2 days of cocoa seed drying from the middle of cocoa fruit. There is no significant interaction between location of cocoa seeds and the drying of cocoa seeds to parameters both of viability and vigor of the cacao seed observed.
\end{abstract}

Keywords: Cocoa seeds, viabilitas, vigor, drying time

\begin{abstract}
ABSTRAK
Penelitian ini bertujuan untuk mengetahui pengaruh letak biji yang berbeda pada buah dan penurunan kadar air benih terhadap viabilitas dan vigor benih kakao. Penelitian ini menggunakan Rancangan Acak Lengkap pola faktorial dengan tiga ulangan. Ada 2 faktor yang diteliti yaitu faktor letak biji pada buah (L) yang terdiri dari dari 3 taraf yaitu : $\left(\mathrm{L}_{1}\right)$ benih bagian pangkal, $\left(\mathrm{L}_{2}\right)$ benih bagian tengah, $\left(\mathrm{L}_{3}\right)$ benih bagian ujung. Sedangkan faktor yang kedua adalah : pengeringan benih $(\mathrm{P})$ yang terdiri dari 3 taraf yaitu : $\left(\mathrm{P}_{0}\right)$ tanpa pengeringan, $\left(\mathrm{P}_{1}\right)$ pengeringan 1 hari, $\left(\mathrm{P}_{2}\right)$ pengeringan 2 hari. Hasil penelitian menunjukkan bahwa Perlakuan letak biji berpengaruh nyata terhadap nilai viabilitas dan vigor benih yang diamati, kecuali terhadap nilai potensi tumbuh benih dan berat kering kecambah normal. Perlakuan terbaik dijumpai pada perlakuan letak biji di bahagian tengah buah $\left(\mathrm{L}_{2}\right)$. Perlakuan pengeringan berpengaruh nyata terhadap nilai viabilitas dan vigor benih yang diamati, kecuali terhadap nilai potensi tumbuh benih dan berat kering kecambah normal. Perlakuan terbaik dijumpai pada perlakuan benih yang dikering anginkan selama 2 hari tengah buah $\left(\mathrm{P}_{2}\right)$.Tidak terdapat terdapat interaksi yang nyata antara perlakuan letak biji dan
\end{abstract}


perlakuan pengeringan benih kakao terhadap semua tolok ukur viabilitas dan vigor benih kakao yang diamati.

Keywords: Cocoa seeds, viabilitas, vigor, drying time

\section{PENDAHULUAN}

Kakao (Theobroma cacao, L.) merupakan salah satu komuniti ekspor nasional Indonesia yang memiliki kontribusi dalam menghasilkan devisa Negara. Seiring dengan bertambahnya jumlah penduduk dunia, permintaan pasar terhadap kakao semakin meningkat dari tahun ke tahun. Kakao yang merupakan salah satu komoditas andalan perkebunan, berperan penting dalam perekonomian Indonesia. Tahun 2010 indonesia menjadi produsen kakao terbesar ke2 di dunia dengan produksi 1,38 juta ton. Kondisi ini merupakan suatu peluang yang baik bagi Indonesia untuk menjadi produsen utama kakao dunia (Direktur Jendral Perkebunan, 2010).

Peningkatan produksi kakao dapat dilakukan antara lain dengan usaha intensifikasi maupun ekstensifikasi. Hal ini dilakukan karena di Indonesia masih banyak lahan yang dapat dimanfaatkan untuk usaha perkebunan kakao. Usaha peningkatan ini tentunya tidak terlepas dari ketersediaan banih kakao dalam jumlah banyak, salah satunya dengan perbanyak benih melalui biji.

Rendahnya produktivitas tanaman kakao merupakan masalah klasik yang hingga kini masih sering dihadapi. Secara umum, rata-rata produktivitas kakao Indonesia sebesar 900 kg/ha/tahun. Angka ini masih jauh dibawah rata-rata potensi yang diharapkan, yakni sebesar $2.000 \mathrm{~kg} / \mathrm{ha} / \mathrm{tahun}$. Selain itu produktivitas tanaman kakao mayoritas disebabkan antara lain karena penggunaan bahan tanam yang kurang baik, teknologi budidaya yang kurang optimal, umur tanaman, serta masalah serangan hama dan penyakit (Wahyudi, 2008).

Hasil penelitian pembibitan
yang cukup menonjol baru
ditemukan pada tahun 1980-an, antara lain mengenai pengaruh posisi biji di dalam buah terhadap kualitas benih. Biasanya penanaman kakao sebagian besar menggunakan bahan tanam asalan, yakni biji yang digunakan tidak jelas asal usulnya. Oleh karena itu, dalam upaya peningkatan produktivitas kakao nasional, salah satu program yang harus dilakukan adalah melakukan peremajaan terhadap tanaman kakao maupun yang tidak produktif, yakni dengan menggunakan bibit unggul.

Mengingat tanaman kakao mempunyai kegunaan yang beragam dalam kehidupan. Untuk itu diperlukan sarana produksi, salah satunya adalah penggunaan benih bermutu, benih kakao yang baik untuk bahan tanam adalah buah yang berasal dari pohon yang produksinya tinggi dan juga resisten terhadap hama dan penyakit (Siregar, et al.1992).

Benih kakao merupakan titik awal dari segala aktivitas pertumbuhan dan perkembangan 
tanaman kakao. Benih kakao berasal dari buah pada batang pokok, cabang dan ranting. Biji yang digunakan sebagai benih dapat berasal dari bagian ujung, tengah dan pangkal buah, kecuali biji yang terlalu kecil. Adapun lokasi biji di dalam buah berpengaruh terhadap kandungan metabolit dari kualitas benih kakao. (Pudji Raharjo, 2011).

Kadar air benih mempengaruhi viabilitas benih rekalsitran. Penurunan kadar air smpai dibawah titik kritisnya mengakibatkan penurunan viabilitas benih secara cepat, sedangkan kadar air benih yang terlampau tinggi menjadi masalah dalam konservasi. Kadar air benih yang terlalu rendah dapat juga mengakibatkan rusaknya lipid protein penyusun membran sel sehingga terjadi kebocoran membran sel. Adapun Pengeringan benih yang dilakukan berpengaruh terhadap rendemen hasil dan daya tahan biji kakao. Pengeringan benih dengan dikering anginkan selama 1 hari, 2 hari dan tanpa pengeringan (Saenong, 1986).

Sifat benih kakao tidak mengikuti kaidah Harrington yang berbunyi "pada kadar air 4-15\%, peningkatan kadar air 1\% dapat menurunkan periode hidup benih setengahnya, Demikian halnya dengan suhu, peningkatan $50{ }^{\circ} \mathrm{C}$ dapat menurunkan umur simpan benih setengahnya, sehingga untuk bertahan dalam proses perkecambahannya kadar air yang tinggi sekitar 30\% (Esrita, 2000).

\section{BAHAN DAN METODE}

\subsection{Tempat dan Waktu Penelitian}

Penelitian dilakukan di Gampong Teumpok Teungoh Kecamatan Banda Sakti Kota Lhokseumawe. Penelitian dilakukan pada bulan Juni sampai dengan Juli 2015.

\subsection{Bahan Dan Alat}

\begin{tabular}{lrrr}
\multicolumn{2}{c}{ Bahan- } & bahan & yang \\
digunakan adalah benih & kakao \\
varietas TSH & 858 , pasir & halus, \\
karung goni. Alat-alat & yang
\end{tabular} digunakan adalah cangkul, ayak, gembor, handsprayer, sera tester dan alat tulis menulis.

\subsection{Metode Penelitian}

Penelitian ini menggunakan Rancangan Acak Lengkap (RAL) faktorial dengan 3 ulangan. Ada dua faktor yang diteliti, yaitu :

1. Faktor letak biji pada buah (L) : benih bagian pangkal $\left(\mathrm{L}_{1}\right)$, benih bagian tengah $\left(\mathrm{L}_{2}\right)$ dan benih bagian ujung $\left(\mathrm{L}_{3}\right)$

2. Faktor Pengeringan Benih $(\mathrm{P})$ : tanpa pengeringan $\left(\mathrm{P}_{0}\right)$, pengeringan 1 hari $\left(\mathrm{P}_{1}\right)$ dan pengeringan 2 hari $\left(\mathrm{P}_{2}\right)$

Data hasil pengamatan di analisis secara statistik dengan menggunakan analisis keragaman untuk Rancangan Acak Lengkap (RAL) dan apabila berpengaruh nyata dan sangat nyata maka dilakukan uji lanjut masing-masing perlakuan dengan menggunakan uji (UJBD).

\subsection{Pelaksanaan Penelitian}

\subsubsection{Persiapan Media}

\section{Perkecambahan}

Media perkecambahan yang akan digunakan adalah dipersiapkan khusus berupa media pasir dengan 
menggunakan box plastik berukuran $25 \times 30 \mathrm{~cm}$. Bahan material yang digunakan untuk media perkecambahan adalah lapisan pasir halus $\pm 10 \mathrm{~cm}$.

\subsubsection{Persiapan Benih}

Buah kakao dipilih buahnya yang diamati langsung dipohon induk bibit kakao di Kecamatan Sawang, buah yang telah dipetik dipisahkan kepada tiga kelompok yaitu ; (1) kelompok yang langsung dikecambahkan, kelompok yang dikeringkan selama 1 hari dan (3) kelompok yang dikeringkan selama 2 hari. Buah kakao dibelah dan biji calon benih yang akan diteliti, juga dipisahkan berdasarkan letak pada buah yaitu ; (1) biji bagian pangkal, (2) biji bagian tengah dan (3) biji bagian ujung. Biji buah kakao dibersihkan dari pulp dengan cara meremasremas biji dengan abu sekam dengan hati-hati agar biji tidak rusak, selanjutnya benih diperlakukan sesuai dengan perlakuan.

\subsubsection{Pengeringan Benih}

Setelah benih di bersihkan dari pulp dan dicuci atau dibilas. Kemudian benih dikering anginkan sesuai perlakuan. Biji kakao tersebut dikelompokkan berdasarkan letak biji pada buah kemudian dibagi kepada 2 kelompok pengeringan, yaitu kelompok yang dikeringkan selama 1 hari dan 2 hari. Untuk memiliki viabilitas dan vigor benih yang lebih baik, benih dikering anginkan didalam suhu ruangan selama 48 jam (2 hari).

\subsubsection{Perkecambahan Benih}

Pekerjaan perkecambahan langsung dilakukan sesuai dengan taraf yang telah ditetapkan yaitu ada 3 taraf perlakuan, yang masingmasing taraf dengan perlakuan yang sama. Taraf pertama adalah terhadap benih yang tanpa pengeringan, dengan langkah-langkah sebagai berikut :

1. Buah dipetik langsung dibelah, diambil biji dan dipisahkan sesuai dengan perlakuan letak biji, kemudian benih dibersihkan pulpnya lalu dibilas.

2. Benih tersebut langsung disemaikan pada media kecambah secara terpisah, dengan posisi bagian calon akar menghadap ke bawah.

3. Benih yang disemai diatur pada media dengan jarak $3 \times 4 \mathrm{~cm}$,

Taraf kedua dan ketiga dilakukan dengan perlakuan yang sama seperti taraf pertama setelah mengalami pengeringan masingmasing 1 hari dan 2 hari.

\subsubsection{Pemeliharaan.}

\begin{tabular}{lr}
\multicolumn{2}{c}{ Pemeliharaan benih yang } \\
dilakukan dengan & menjaga \\
kelembabannya. & Penyiraman \\
dilakukan setiap hari. &
\end{tabular}

\subsubsection{Pengamatan dan Analisis Data}

Pengamatan dilakukan terhadap tolok ukur viabilitas dan vigor benih. Viabilitas benih adalah kemampuan benih untuk tumbuh secara normal pada kondisi yang optimum, viabilitas benih dapat diamati meliputi : Potensi Tumbuh Maksimum (\%) dan Daya Berkecambah benih (\%). Sedangkan Vigor benih adalah kemampuan benih untuk tumbuh secara normal 
pada kondisi yang sub-optimum, vigor benih yang diamati adalah : Indeks Vigor benih (\%), Kecepatan Tumbuh benih (\%) dan Keserempakan Tumbuh benih (\%).

\section{HASIL DAN PEMBAHASAN}

\subsection{Pengaruh Letak Biji Terhadap Viabilitas Benih Kakao}

Hasil analisis ragam menunjukkan bahwa perlakuan letak biji tidak berpengaruh nyata terhadap potensi tumbuh benih kakao, tetapi berpengaruh sangat nyata terhadap daya berkecambah dan indeks vigor beni kakao. Rata-rata potensi tumbuh, daya berkecambah dan indeks vigor benih kakao akibat perlakuan letak biji dapat dilihat pada Tabel 1.

Tabel 1. Rata-rata potensi tumbuh, daya berkecambah dan indeks vigor benih kakao akibat perlakuan letak biji yang berbeda

\begin{tabular}{cccc}
\hline $\begin{array}{c}\text { Perlakuan } \\
\text { Letak Biji }\end{array}$ & $\begin{array}{c}\text { Potensi } \\
\text { Tumbuh Benih } \\
(\%)\end{array}$ & $\begin{array}{c}\text { Daya Berkecambah Indeks Vigor Benih } \\
\text { Benih }(\%)\end{array}$ & $(\%)$ \\
Pada Buah & $97,33 \mathrm{a}$ & $90,89 \mathrm{~b}$ & $58,22 \mathrm{~b}$ \\
$\mathrm{~L}_{1}$ & $97,78 \mathrm{a}$ & $94,67 \mathrm{~b}$ & $61,33 \mathrm{~b}$ \\
$\mathrm{~L}_{2}$ & $94,44 \mathrm{a}$ & $85,56 \mathrm{a}$ & $49,78 \mathrm{a}$ \\
$\mathrm{L}_{3}$ & th & 5,27 & 6,37 \\
\hline UJBD 0.05 & &
\end{tabular}

Keterangan: Angka yang diikuti huruf yang sama pada kolom yang sama berpengaruh tidak nyata menurut UJBD pada taraf 0,05

Tabel 1 menunjukkan bahwa letak biji tidak mempengaruhi potensi tumbuh benih kakao. Potensi tumbuh benih tertinggi dijumpai pada perlakuan letak biji dibagian tengah buah $\left(\mathrm{L}_{2}\right)$ yaitu sebesar $97.78 \%$, sedangkan potensi tumbuh benih terendah dijumpai pada perlakuan letak biji dibagian ujung buah $\left(\mathrm{L}_{3}\right)$ yaitu sebesar $94.44 \%$. hal ini diduga terjadi karena Biji yang terletak di bagian tengah buah memiliki ukuran yang lebih besar jika dibandingkan dengan bagian ujung ataupun pangkal. Dengan demikian, secara kuantitatif, biji yang berukuran besar jumlah cadangan makanan akan semakin banyak sehingga dapat mencukupi kebutuhan hidupnya (Hendrata dan Sutardi, 2009).

Tabel 1 juga menunjukkan bahwa letak biji dapat mempengaruhi daya berkecambah dan indeks vigor benih kakao yang diamati. Daya berkecambah benih tertinggi dijumpai pada perlakuan letak biji dibagian tengah buah $\left(\mathrm{L}_{2}\right)$ yaitu sebesar $94.67 \%$, sedangkan daya berkecambah benih terendah dijumpai pada perlakuan letak biji dibagian ujung buah $\left(\mathrm{L}_{3}\right)$ yaitu sebesar $85.56 \%$. Nilai indeks vigor benih tertinggi dijumpai pada perlakuan letak biji dibagian tengah buah $\left(\mathrm{L}_{2}\right)$ yaitu sebesar 61,33 \%, sedangkan Indeks vigor benih terendah dijumpai pada perlakuan letak biji dibagian ujung buah $\left(\mathrm{L}_{3}\right)$ yaitu sebesar $49,78 \%$.

Sutopo (2002) menyatakan bahwa benih yang besar dan berat memiliki cadangan makanan yang banyak atau juga bisa karena memiliki embrio yang besar. Makin besar dan berat ukuran benih, maka kandungan protein dalam benih juga akan semakin banyak. Berat benih 
sangat menentukan kecepatan pertumbuhan dan produksi karena pada benih yang berat akan dihasilkan kecambah yang besar pada saat permulaan dan berat tanaman yang tinggi pada saat tanaman dipanen.

\subsection{Pengaruh Letak Biji Terhadap Vigor Benih Kakao}

Hasil analisis ragam menunjukkan bahwa perlakuan letak biji berpengaruh nyata terhadap nilai vigor benih kakao yang diamati. Rata-rata kecepatan tumbuh, keserempakan tumbuh benih dan berat kering kecambah normal akibat perlakuan letak biji dapat dilihat pada Tabel 2 berikut.

Tabel 2. Rata-rata kecepatan tumbuh, keserempakan tumbuh benih dan berat kering kecambah normal akibat perlakuan letak biji yang berbeda

\begin{tabular}{cccc}
\hline $\begin{array}{c}\text { Perlakuan } \\
\text { Letak Biji }\end{array}$ & $\begin{array}{c}\text { Kecepatan Tumbuh } \\
\text { Benih } \\
\text { Pada buah }\end{array}$ & $\begin{array}{c}\text { Keserempakan } \\
\text { Tumbuh Benih }\end{array}$ & $\begin{array}{c}\text { Berat Kering } \\
(\%)\end{array}$ \\
\hline L1 & $68,87 \mathrm{~b}$ & $85,78 \mathrm{~b}$ & $11,12 \mathrm{a}$ \\
L2 & $72,41 \mathrm{~b}$ & $88,44 \mathrm{~b}$ & $12,34 \mathrm{a}$ \\
L3 & $61,14 \mathrm{a}$ & $78,22 \mathrm{a}$ & $12,09 \mathrm{a}$ \\
\hline UJBD 0.05 & 5,41 & 6,33 & tn
\end{tabular}

Keterangan: Angka yang diikuti huruf yang sama pada kolom yang sama berpengaruh tidak nyata menurut UJBD pada taraf 0,05

Tabel 2 menunjukkan bahwa perlakuan letak biji dapat mempengaruhi kecepatan dan keserempakan tumbuh benih kakao. Kecepatan tumbuh benih tertinggi dijumpai pada perlakuan letak biji dibagian tengah buah $\left(\mathrm{L}_{2}\right)$ yaitu sebesar $94.67 \%$, sedangkan kecepatan tumbuh benih terendah dijumpai pada posisi letak biji di bagian ujung buah $\left(\mathrm{L}_{3}\right)$ yaitu sebesar 85.56\%. Keserempakan tumbuh benih tertinggi dijumpai pada yang terletak di bagian tengah buah $\left(\mathrm{L}_{2}\right)$ yaitu sebesar 88,44 \%, sedangkan terendah dijumpai pada perlakuan letak biji dibagian ujung buah $\left(\mathrm{L}_{3}\right)$ yaitu $78,22 \%$.

Tabel 2 juga menunjukkan bahwa perlakuan letak biji tidak mempengaruhi berat kering kecambah normal kakao. Namun berat kering kecambah normal kakao tertinggi dijumpai pada bagian tengah buah $\left(\mathrm{L}_{2}\right)$ yaitu sebesar12,34 mg, sedangkan berat kering kecambah normal kakao terendah dijumpai pada bagian pangkal buah $\left(\mathrm{L}_{1}\right)$ yaitu sebesar $11,12 \mathrm{mg}$.

Dari hasil penelitian yang dilakukan yang disajikan pada Tabel $3,4,5,6,7$ dan 8 dapat lihat bahwa perlakuan letak biji pada bahagian tengah buah $\left(\mathrm{L}_{2}\right)$ memberikan hasil viabilitas dan vigor benih kakao yang lebih tinggi dibandingkan biji yang terletak pada bagian pangkal buah $\left(\mathrm{L}_{1}\right)$ dan ujung buah $\left(\mathrm{L}_{3}\right)$, hal ini diduga terjadi karena pada bahagian tengah buah terdapat benih yang berkembang secara sempurna baik secara fisiologis maupun secara biokimia benih, kenyataan ini sesuai dengan pendapat Setiawan (1982) yang menyatakan bahwa Biji yang baik adalah yang berasal dari bagian 
tengah buah, yaitu $2 / 3$ bagian dari untaian biji. Biji yang terletak di bagian tengah menunjukkan persentase kerusakan dan biji yang tidak tumbuh terkecil serta daya dan panjang kecambah terbesar (Latif, 1982).

\subsection{Pengaruh Perlakuan Pengeringan Terhadap Vigor Benih Kakao}

Hasil analisis ragam menunjukkan bahwa perlakuan peneringan tidak berpengaruh nyata terhadap potensi tumbuh benih kakao, tetapi berpengaruh sangat nyata terhadap daya berkecambah dan indeks vigor benih kakao. Ratarata potensi tumbuh, daya berkecambah dan indeks vigor benih kakao akibat perlakuan pengeringan benih dapat dilihat pada Tabel 2 berikut.

Tabel 3 menunjukkan bahwa perlakuan pengeringan benih tidak mempengaruhi potensi tumbuh benih kakao. Namun potensi tumbuh benih tertinggi dijumpai pada perlakuan pengeringan benih selama dua hari $\left(\mathrm{P}_{2}\right)$ yaitu sebesar 97.78\%, sedangkan potensi tumbuh benih terendah dijumpai pada perlakuan pengeringan benih selama satu hari $\left(\mathrm{P}_{1}\right)$ yaitu sebesar $94.89 \%$.

Tabel 3. Rata-rata potensi tumbuh, daya berkecambah dan indeks vigor benih kakao akibat perlakuan pengeringan benih yang berbeda

\begin{tabular}{cccc}
\hline $\begin{array}{c}\text { Perlakuan } \\
\text { Pengeringan } \\
\text { Benih }\end{array}$ & $\begin{array}{c}\text { Potensi Tumbuh } \\
\text { Benih } \\
(\%)\end{array}$ & $\begin{array}{c}\text { Daya Berkecambah Indeks Vigor Benih } \\
\text { Benih }(\%)\end{array}$ & $(\%)$ \\
\hline $\mathrm{P}_{0}$ & $96,89 \mathrm{a}$ & $92,00 \mathrm{a}$ & $53,78 \mathrm{~b}$ \\
$\mathrm{P}_{1}$ & $94,89 \mathrm{a}$ & $85,56 \mathrm{~b}$ & $47,33 \mathrm{~b}$ \\
$\mathrm{P}_{2}$ & $97,78 \mathrm{a}$ & $93,56 \mathrm{a}$ & $68,22 \mathrm{a}$ \\
\hline UJBD 0.05 & tn & $\mathbf{5 , 2 7}$ & 6,37 \\
\hline
\end{tabular}

Keterangan: Angka yang diikuti huruf yang sama pada kolom yang sama berpengaruh tidak nyata menurut UJBD pada taraf 0,05

Tabel 3 juga menunjukkan bahwa perlakuan pengeringan benih dapat mempengaruhi daya berkecambah dan indeks vigor benih kakao yang diamati. Daya berkecambah benih tertinggi dijumpai pada pengeringan benih selama dua hari $\left(\mathrm{P}_{2}\right)$ yaitu sebesar 94.67\%, sedangkan daya berkecambah benih terendah dijumpai pada perlakuan pengeringan benih selama satu hari $\left(\mathrm{P}_{1}\right)$ yaitu sebesar $85.56 \%$. Nilai indeks vigor benih tertinggi dijumpai pada pengeringan benih selama dua hari $\left(\mathrm{P}_{2}\right)$ yaitu sebesar 68,22 \%, sedangkan Indeks vigor benih terendah dijumpai pada perlakuan pengeringan benih selama satu hari $\left(\mathrm{P}_{1}\right)$ yaitu sebesar $47,33 \%$.

\subsection{Pengaruh Perlakuan Pengeringan Terhadap Viabilitas Benih Kakao}

Hasil analisis ragam menunjukkan bahwa perlakuan pengeringan benih berpengaruh sangat nyata terhadap kecepatan tumbuh dan keserempakan tumbuh benih kakao, tetapi tidak berpengaru pada berat kering kecambah normal. Rata-rata kecepatan tumbuh, keserempakan tumbuh benih dan 
berat kering kecambah normal akibat perlakuan pengeringan benih dapat dilihat pada Tabel 4 berikut.

Tabel 4 menunjukkan bahwa perlakuan pengeringan benih dapat mempengaruhi kecepatan tumbuh dan keserempakan tumbuh benih kakao yang diamati. Kecepatan tumbuh benih tertinggi dijumpai pada perlakuan pengeringan benih selama dua hari $\left(\mathrm{P}_{2}\right)$ yaitu sebesar 76,63 \%, sedangkan kecepatan tumbuh benih terendah dijumpai pada perlakuan pengeringan benih selama satu hari $\left(\mathrm{P}_{1}\right)$ yaitu sebesar $54,88 \%$. Keserempakan tumbuh benih tertinggi dijumpai pada perlakuan pengeringan benih selama dua hari $\left(\mathrm{P}_{2}\right)$ yaitu sebesar 88,44\%, sedangkan keserempakan tumbuh benih terendah dijumpai pada perlakuan pengeringan benih selama satu hari $\left(\mathrm{P}_{1}\right)$ yaitu sebesar 78,22\%.

Tabel 4. Rata-rata kecepatan tumbuh, keserempakan tumbuh benih dan berat kering kecambah normal benih kakao akibat perlakuan pengeringan benih yang berbeda

\begin{tabular}{cccc}
\hline $\begin{array}{c}\text { Perlakuan } \\
\text { Pengeringan } \\
\text { Benih }\end{array}$ & $\begin{array}{c}\text { Kecepatan } \\
\text { Tumbuh Benih } \\
(\%)\end{array}$ & $\begin{array}{c}\text { Keserempakan } \\
\text { Tumbuh Benih }(\%)\end{array}$ & $\begin{array}{c}\text { Berat Kering } \\
\text { Kecambah Normal } \\
(\mathrm{mg})\end{array}$ \\
\hline $\mathrm{P}_{0}$ & $65,91 \mathrm{~b}$ & $82,88 \mathrm{~b}$ & $12,06 \mathrm{a}$ \\
$\mathrm{P}_{1}$ & $54,88 \mathrm{c}$ & $77,78 \mathrm{c}$ & $11,63 \mathrm{a}$ \\
$\mathrm{P}_{2}$ & $76,63 \mathrm{a}$ & $97,78 \mathrm{a}$ & $11,85 \mathrm{a}$ \\
\hline UJBD 0.05 & 5,41 & 6,33 & tn
\end{tabular}

Keterangan: Angka yang diikuti huruf yang sama pada kolom yang sama berpengaruh tidak nyata menurut UJBD pada taraf 0,05

Tabel 4 juga menunjukkan bahwa perlakuan pengeringan benih tidak mempengaruhi berat kering kecambah normal kakao. Namun berat kering kecambah normal kakao tertinggi dijumpai pada perlakuan tanpa pengeringan $\left(\mathrm{P}_{0}\right)$ yaitu sebesar $12,06 \mathrm{mg}$, sedangkan berat kering kecambah normal kakao terendah dijumpai pada perlakuan pengeringan benih selama satu hari $\left(\mathrm{P}_{1}\right)$ yaitu sebesar 11,63 mg.

Dari hasil penelitian yang dilakukan yang disajikan pada tabel 3,4,5,6,7 dan 8 dapat lihat bahwa perlakuan pengeringan benih yang dilakukan dengan dikering anginkan selama dua hari $\left(\mathrm{P}_{2}\right)$ memberikan hasil viabilitas dan vigor benih kakao yang lebih tinggi dibandingkan tanpa dikering anginkan $\left(\mathrm{P}_{0}\right)$ dan yang dikering anginkan selama satu hari $\left(\mathrm{P}_{1}\right)$, hal ini diduga terjadi karena pada pengeringan benih yang dilakukan dengan dikering anginkan selama dua hari benih telah mengalami perubahan baik secara fisiologis maupun secara biokemia benih. Benih yang telah dikering anginkan selama dua hari diduga telah mencapai kadar air benih yang ideal untuk memulai perkecambahan, selain itu benih diduga telah mengalami proses pematangan embrio sehingga benih telah lebih siap untuk berkecambah secara optimal. 
Kenyataan diatas didukung oleh Balitbang Pertanian (2012) yang menyatakan bahwa benih yang memiliki kadar air benih ideal dan embrio yang sudah berkembang baik akan memiliki viabilitas dan vigor benih yang lebih baik. Selain sangat berpengaruh terhadap rendemen hasil, kadar air berpengaruh pada daya tahan biji kakao terhadap kerusakan terutama saat penggundangan dan pengangkutan. Biji kakao yang mempunyai kadar air tinggi, sangat rentan terhadap serangan jamur dan serangga.

\subsection{Pengaruh Interaksi Perlakuan}

Hasil analisis ragam menunjukkan bahwa Tidak dijumpai interaksi perlakuan yang nyata terhadap semua tolok ukur viabilitas dan vigor benih kakao yang diamati. Hal ini diduga antara perlakuan letak biji tidak mempengaruhi perlakuan pengeringan benih atau sebaliknya, dengan kata lain masing-masing perlakuan berdiri bebas.

\section{KESIMPULAN DAN SARAN}

\subsection{Kesimpulan}

1. Letak biji bahagian tengah buah memberikan pengaruh yang paling baik terhadap daya berkecambah, indeks vigor, kecepatan tumbuh dan keserempakan tumbuh benih kakao.

2. Perlakuan pengeringan yang dikering anginkan selama 2 hari tengah buah memberikan pengaruh yang paling terhadap daya berkecambah, indeks vigor, kecepatan tumbuh dan keserempakan tumbuh benih kakao.

\subsection{Saran.}

Untuk mendapatkan viabilitas dan vigor benih kakao yang baik dapat menggunakan benih kakao yang terletak pada bahagian tengah buah yang dikering anginkan selama 2 hari.

\section{DAFTAR PUSTAKA}

Balitbang Pertanian, 2012. Standar Operasional Fermentasi Kakao. http://prima tani. Litbang. deptan.go.id. Diakses pada 11 Januari 2012.

Hendra R dan Sutardi. 2009. Respon bibit kakao pada bagian pangkal, tengah, dan pucuk terhadap pemupukan majemuk. Agrovigor 2: 103109

Sutopo, Lita. 2002. Teknologi Benih. Rajawali Pers, Jakarta.

Siregar, T.H., S. Riyadi, dan L. Nuraeni. 1994. Budidaya, Pengolahan, dan Pemasaran Coklat. Penebar Swadaya, Jakarta

Sutopo, L. 2004. Teknologi Benih. Rajawali Pers, Jakarta

Wahyudi T, T.R. Panggabean, dan Pujiyanto, 2008. Panduan Lengkap Kakao. Penebar Swadaya.Jakarta. 